\title{
Methodology-as-Technique and the Meaning of Rigor in Globalized Management
}

\section{$\underline{\text { Research }}$}

\author{
Emma Bell
}

Keele Management School, Keele University, Staffordshire ST5 5BG, UK

e.bell@keele.ac.uk

Tel: $+44(0) 1782733424$

Nivedita Kothiyal

Institute of Rural Management Anand (IRMA), Anand, Gujarat, 388001, India nivedita@irma.ac.in

Hugh Willmott

Cass Business School, City University London, London EC1Y 8TZ, UK hr22@dial.pipex.com

(Paper accepted for publication in British Journal of Management) 


\begin{abstract}
This article analyses the genre of 'methodology-as-technique' (Hammersley, 2011) which we suggest provides the underpinning logic for a particular conception of scientific rigour that is increasingly regarded as normal in globalized management research. Based on a qualitative interview study of management researchers in the peripheral context of India, we associate the methodology-as-technique genre with social scientific methods of organizing, conducting and disseminating knowledge founded on Western neo-imperialism and colonialism. Our analysis draws attention to the consequences of the genre of methodology-as-technique which relate to a narrowing and displacement of research goals, erasure of context, and devaluation and marginalization of alternatives. By providing insight into how methodology-astechnique comes to dominate in peripheral locations such as India, we suggest that these normative constraints also present an opportunity for denaturalization, by making what is increasingly seen as normal appear alien or strange. We conclude by arguing that countering restrictive definitions of rigor in management research relies on development of a more expansive and inclusive conception of the global that fosters indigenous ways of knowing and promotes decolonizing methodologies.
\end{abstract}

Keywords: methodology; genres; knowledge production; rigor; globalization; denaturalization 
This whole concept of scientific research is something which bothers me... If you do a good qualitative analysis, it is not considered and qualified to be scientific research. It is still subject to bias. But if you do quantitative analysis, it is objective. So... the tendency today is to get into quantitative research... Management is... getting removed from the social sciences... It is becoming more economics and all the rest is seen as... superficial and not substantial; that's the problem. (Paul, dean of faculty)

\section{Introduction}

The enduring, heated nature of rigor-relevance debates, and proliferation of methods textbooks, articles and training programs, suggests an on-going preoccupation with the pursuit of methodological rigor in management research. Positivist quantitative research is widely supposed to be more rigorous than other methodologies (Daft, 1980; Shrivastava, 1987), as it is considered capable of delivering a unified body of knowledge based upon systematic theory development and testing. More 'rigorous' methods are promoted as a way of developing 'stronger' theory and/or producing knowledge that is less context-contingent and more 'generalizable' (Aram and Salipante, 2003, p.190). Yet despite the prominence of rigor in management research, the practices through which researchers construct the meaning of rigor are less well understood.

This can obscure important contextual and discipline-specific differences in how rigor is defined. In disciplines aligned to a positivist philosophy of science, the meaning of rigor is ostensibly settled and taken for granted. In those disciplines more closely aligned to a hermeneutical philosophy of science, unitary conceptions of rigor are considered to 
oversimplify ontological and epistemological differences and complexities (Becher, 1989; Abbott, 2004). Here we understand research as a socially embedded activity conducted within pluralistic communities of practice (Knorr Cetina, 1999; Schwartz-Shea, 2014) that enact particular methodologies through which particular notions of rigor are and framed and institutionalized.

We reflect upon a conception of rigor that currently dominates management research globally. Our empirical focus is India, an emerging economy where management research is becoming more 'internationally' ${ }^{\text {i }}$ oriented (Saunders et al, 2011). Through a process of 'problematization’ (Alvesson and Sandberg, 2011), we examine the socio-historical and institutional conditions that have led to the naturalization of a positivist conception of rigor and marginalisation of alternatives. In the following section, we provide an overview of debates about the globalization of management research and core-periphery dynamics that shape knowledge production. Next, we analyse how researchers in India engage with the notion of rigor, showing how this engagement is closely aligned with what Hammersley (2011) characterizes as the genre of ‘methodology-as-technique’. Hammersley (2011) identifies methodology-as-technique as one of three broad genres of social scientific research that have emerged in the West over the past 50 years ${ }^{\mathrm{ii}}$. This genre is distinguished by attempts 'to codify the methods social scientists use, specifying their character and proper application in relation to the different research tasks' (Hammersley, 2011, p.20-21). Issues of methodology are translated into ‘a relatively small number of clearly defined options’ chosen either based on fit between the research problem and the method of studying it, or 'as a matter of taste' (2011, p.21). Finally, we consider the implications of methodology-astechnique in understanding the meaning of rigor in management research. 
Rigor is often invoked as an ostensibly objective, universal means of evaluating research quality. Our analysis illuminates how, in practice, rigor is a socially constructed and contested concept that, in its dominant form, closely corresponds to the genre of methodology-as-technique and routinely privileges positivistic methods of producing knowledge. The focus of our analysis is the expansion of management research in an emergent, industrialising economy but we suggest similar pressures affect researchers in Western contexts. We endeavour to illuminate this hegemonic process by giving voice to management researchers in the peripheral location of India. Through this we attend to the homogenizing and detrimental effects of such universalistic conceptions of rigor founded on historically and culturally contingent Western philosophical and methodological traditions. In the process, alternatives, including methodologies and methods that are potentially valuable in researching indigenous forms of knowledge, are delegitimised and marginalised. Yet our analysis also suggests that the periphery can offer an instructive vantage point from which not only to observe and respond to these homogenising developments but also to question and disarm them.

\section{The globalization of management research}

The globalization of social science raises concerns about neo-colonialist reproduction of core-periphery dynamics between global North and South with regard to methodological practice and norms of knowledge production (Alatas, 2003; Gobo, 2011). Colonizing practices of knowledge production rely on the formation and unidirectional spread of methods of knowledge creation that are rooted in a concept of science as 'the all-embracing method for gaining an understanding of the world' (Smith, 1999, p.68). Research methodologies developed during the twentieth century, especially those originating in the US 
since the 1950s, are proposed as a 'sort of general knowledge' (Ryen and Gobo, 2011: 411, emphasis in original).

Globalized methodologies foster a homogeneous form of knowledge creation based on 'context-free' methodological principles and methods practices as the means to generate value-free, apolitical knowledge. Based on empiricism and measurement and a way of progressing towards 'truth’ (Gilles and Aldred, 2012), this approach to knowledge assumes all contexts are knowable, in the same way and from the same point of view (Connell, 2007). Globalization is facilitated by training researchers from the global South in Western universities, where they are exposed to a limited range of methodological literatures via journals, handbooks and textbooks. This spread of Western practices of social scientific knowledge creation is suggested to have devalued and marginalized traditional forms of inquiry and local cultural knowledge (Gobo, 2011).

In management research, neo-colonial power relations in shape practices of knowledge production that maintain researchers located in the periphery in a relationship of academic dependency on the West (Jack and Westwood, 2006; Srinivas, 2008; Westwood et al., 2014). Research and publishing in management studies has been shown to be dominated by Western agendas and orientations (Murphy and Zhu, 2012; Li and Parker, 2013) which determine theoretical, epistemological, methodological and stylistic norms (Ibbaro-Colado, 2006). This hegemony positions researchers from peripheral locations, especially those who speak a language other than English, as subaltern (Meriläinen et al., 2008). Management knowledge within the Western centre is dominated by 'US-style research' (Üsdiken, 2014) and is based predominantly on a positivist functionalist orthodoxy (Grey, 2010). Üsdiken’s (2014) analysis of articles in ‘top’ US journals finds a steady decline in qualitative articles and no suggestion 
of novelty in the periphery (non-US/Europe), in terms of methods employed. He concludes that the periphery 'appears to be poised to contribute increasingly to an even greater dominance of US-style research across the world (c.f. Baum, 2007)’ (Üsdiken, 2014, p.784), despite an increasing number of non-US based academics publishing in 'A' journals. This suggests institutional shifts driven by business school accreditation and ranking systems have incentivised the spread of this 'research paradigm' across the globe (Mingers and Willmott, 2013). Consequently, the centre continues to act as a focus of attention and source of influence for the periphery, fostering dependence and remaining largely closed to context. This trend has prompted calls for greater geographical diversity in the creation of global management knowledge to counteract homogenising tendencies towards the North American ‘research paradigm’ which depresses innovative ideas and theories (Tsui, 2007).

While previous analyses have addressed the regimes that support the reproduction and extension of a global Northern 'normal science' in management research, our analysis focuses on how 'US-style research', characterized by Ghoshal (2005, p.81) as studies that 'readily yield[s] sharp, testable propositions and provide[s] simple, reductionist prescriptions', has become dominant in peripheral locations such as India. To this end, we consider how a particular conception of methodological rigor has contributed to extending the reach and dominance of this approach to the production of knowledge. This, we argue, is important in appreciating the practical dynamics of core-periphery relations of knowledge production and fostering greater pluralism and greater methodological innovation in our field. Before analysing the effects of core-periphery dynamics on management knowledge in India, we offer a brief introduction to the context of our empirical study.

\section{The case of India}


Post-independence, the legacy of colonialism in India resulted in new relations of power and dependency arising from the political 'nation-building' project that aimed to improve society and grow the economy through the creation of knowledge, especially in applied research fields (Singh, 1986). This political context contributed to the development of management education and research in India through the establishment of Indian Institutes of Management (IIMs) in Ahmedabad and Calcutta in the early 1960s ${ }^{\mathrm{iii}}$ in collaboration with Harvard University and MIT, financially supported by the Ford Foundation (Srinivas, 2008; Mohan, 2011). The transfer of 'scientific' (Mohan, 2011) management knowledge from the technologically advanced, affluent centre, specifically the US, to the economically poor, technologically underdeveloped periphery was seen as key to improving managerial efficiency and promoting modernization (Mir et al. 2004). Srivinas (2008) identifies two early phases of Indian management knowledge production: 'mimicry’ (1959-1975) and 'revival' (1976-1990). Mimicry was characterised by uncritical acceptance of knowledge transfer from the US via the IIMs. Revival problematized universalistic knowledge transfer by questioning its relevance to the Indian context and encouraging development of management theory and concepts more relevant to Indian industry and managers. After 1990, economic reforms associated with the LPG model (Liberalization, Privatization, Globalization) resulted in local relevance being overtaken by an ambition to develop a 'global perspective' and produce 'global managers' (Sheth, 1991). The past decade has been characterized by rapid growth in Indian business school education (FICCI, 2011). This has stimulated concerns about research quality (Khatri et al., 2012; Sheel and Vohra, 2014: Panda and Gupta, 2014), particularly in elite institutions like IIMs, where university managers have sought to enhance research quality based on international business school rankings (Banerjee, 2013). Consequently, Indian researchers encounter pressure to publish in 'the 40 top-tier 
US/Western journals identified by the Financial Times' and failure to do so can result in them being deemed to fall short of 'global standards' (Khatri et al., 2012, p.105).

Similar trajectories relating to the Americanization of management research and education have been traced in other peripheral contexts including Brazil (Alcadipani and Caldas, 2012), where political efforts and resource investment since the 1960s have concentrated on enhancing the scientific legitimacy through disciplinary rigor, promoting quantitative methods and sending scholars to the US for research training (Cooke and Alcadipani, 2015). Management researchers in South Africa are also increasingly encouraged to publish in international journals as universities have sought to increase research output and impact and move up the global rankings (Nkomo, 2015). Hence we suggest India is not unique and forms part of a pattern of globalization of management research based on Western neo-imperialism and colonialism.

\section{Data collection and analysis}

Methodologically, we engage in an experience-near approach (Geertz, 1974) that focuses on the everyday life-worlds that actors inhabit and render meaningful. Our approach is interpretive in the sense that we are attentive to actor(s) frame(s) of reference. We assume that 'people act in terms of their own and not the observer's definition of the situation' (Silverman, 1970, p.37) although, as our study demonstrates, the observer's definitions may become internalized by participants. We also assume that actions are enabled but also constrained by distinctive socio-cultural frames of reference that position us in ways that affect our insider/outsider status as we explore institutional practices of management knowledge production and their colonizing effects within a global system. 
Our analysis is based on iterative, abductive movement between methodological literatures and empirical data generated through qualitative interviews and content analysis of selected methods texts. Thirty-one semi-structured interviews were carried out by the first two authors with 31 management researchers in India at a cross-section of institutional types (IIMs, state funded universities, ‘deemed’ universities, autonomous non-profit management institutes, private business schools), and hierarchical levels (professors, associate and assistant professors). Our study also considered the role of the Indian diaspora in the US and UK through a further five interviews. Each interview lasted approximately one hour and was professionally transcribed verbatim, with the exception of one respondent who preferred to answer questions via an exchange of emails. Interviews focused on the researcher's career and academic socialization as well as their methodological choices over time. Half were conducted face-to-face, either at the interviewee's institution or at conferences. The rest were conducted via Skype, an increasingly recognized and convenient method of qualitative interviewing (Hanna, 2012).

Analysis began by reading the transcripts closely several times before uploading the data into NVivo and coding emergent first-order themes (e.g. 'publishing pressures', 'research training', 'research quality'). Iterative, first-order coding of recurrent terms used by interviewees, such as 'technique', formed the basis for ongoing data collection and development of theoretically-informed categories. Abductive reasoning led to back and forth engagement between the data and the literature to identify the most appropriate interpretation (Atkinson et al., 2003). Interviewing ceased when insights generated from new data became less frequent. We purposively sampled to ensure that our respondents represented a diverse range of methodological orientations; based on their interview accounts we identified 13 as 
positivist-quantitative, 10 as positivist-qualitative or mixed methods with a positivist orientation, and 13 as interpretive-qualitative and/or critical. Gender distribution was 25 male, 11 female.

In addition, our research incorporated qualitative content analysis of three leading management research methods textbooks in India (Cooper and Schindler, 2011; Zikmund et al., 2010; Chawla and Sondhi, 2011) ${ }^{\text {iv }}$. By making authoritative claims about what it means to 'do' research, and the meaning of terms such as 'scientific' in a given field (Schwartz-Shea and Yanow, 2002), textbooks reflect the boundaries of legitimate research methodologies and provide a proxy indication of what is taught to novitiate researchers. Following Paulus et al. (2013), we analysed discursive patterns, including coverage, tone and detail, and the legitimacy attributed to quantitative and qualitative methodological orientations ${ }^{\mathrm{v}}$.

In recognition of the core-periphery dynamics that exist between the authors, we draw on the concepts of 'bicultural' (Smith, 1999) and 'decolonizing' research (Swadener and Mutua, 2008) to explore how non-indigenous researchers from the centre can work with, and try to bring in, non-Western voices from the periphery. This involved reflecting on the power relations entailed in our collaboration, which combines interpretive epistemology with elements of a more critical orientation to challenging as well as understanding the social world (Alvesson and Deetz, 2000). We have also tried to be mindful of how the format, process and/or outcomes of our own research 'might reify hegemonic power structures, thereby creating marginality’ (Swadener and Mutua, 2008, p.33), including submission to a peer-review journal process as a way of disseminating the research.

\section{Methodology-as-technique in Indian management research}


Through iterative analysis of respondents accounts we began to discern a recurrent pattern of methodological practice that corresponded closely to the genre of 'methodology-astechnique' (Hammersley, 2011). As we repeatedly revisited our data, we found this conception of methodology to be highly pertinent, as indicated by interviewees’ multiple references to 'interview technique', 'econometric techniques', 'tools and techniques', 'quantitative techniques', 'interpretive techniques', 'observation techniques', 'participatory techniques' and 'modern technique’. Hammersley (2011) disaggregates ‘methodology-astechnique' into four overlapping elements: proceduralism; privileging quantitative-positivist methods; criteriology and methodolatry. As we now show, there is a strong but also equivocal resonance between the primary orientation of our research participants, as articulated by them, and the 'methodology-as-technique' genre.

\section{Proceduralism}

Proceduralism is governed by the assumption that good research practice relies on following a set of rules or prescribed sequence of steps (Schwandt, 1996) that can be made explicit 'as a set of prescriptive dos and don’ts' (Hammersley 2011, p.21). While such codification is common in quantitative research, it can extend to qualitative research where there is an aspiration to standardise according to a realist ideal of procedural objectivity (Newell, 1986). Proceduralism is often seen as a way of minimising 'subjectivity'. As assistant professor Shubra advocates:

choice of research methods should be driven by the problem that you are trying to solve or the question that you are trying to raise... I... give [my students] a map... if you have questions like this and the phenomena like this... what is the logical choice that researchers should ideally take in [their] method? 
Proceduralism promotes a view of the researcher as a technician who is 'given a problem to solve by others... accept[s] the terms in which it has been defined, and deploy[s] their technical expertise in doing this' (Hammersley, 2011, p.73). This is reinforced by methods textbooks that depict research as a smooth and predictable process. When adopting ‘systematic, empirically based procedures for generating replicable research’ (Cooper and Schindler, 2011, p.12), research is understood to take the form of 'an unbiased, structured, and sequential method of enquiry' (Chawla and Sondhi, 2011, p.5).

Proceduralism is congruent with modernist notions of progress - the idea that for management research to become established and credible, knowledge production practices must be rational and scientific or, at least, demonstrate compliance with idealized conventions of science, as the following textbook extract attests,

[b]usiness research is the application of scientific method in searching for the truth... any information generated should be accurate and objective... the researcher must be personally detached and free of bias in attempting to find truth... The scientific method is the way researchers go about using knowledge and evidence to reach objective conclusions about the real world. The scientific method is the same in social sciences, such as business, as in physical sciences, such as physics. (Zikmund et al., 2010, p.5)

In the three leading Indian management research textbooks we analysed there was very limited discussion of qualitative methods, in contrast to extensive coverage of quantitative methods and statistical techniques. ${ }^{\text {vi }}$ Qualitative inquiry is thereby ascribed a supplementary role, principally as an exploratory technique that enables hypothesis development. There is almost no explicit consideration of underlying ontological, epistemological and 
methodological assumptions, and little consideration of the breadth of qualitative methods in management research (Bluhm et al., 2011).

\section{Privileging positivist-quantitative methods}

The second aspect of methodology-as-technique concerns the privileging of positivistquantitative methods to bestow scientific legitimacy and credibility on the discipline (Bryman, 1998). The use of methods that enable quantification can be understood as a technology of distance which relies on abstraction and simplification of complex qualitative information (Scott, 1998; Nigam and Turjillo, 2016). This form of knowing is enabled by processes of categorization that determine which data will be analysed, versus that which will be overlooked. The power of quantification arises from performativity, the presentation of data as objective social facts that are accepted as a basis for action. In India, quantification as a foundation of social science research and a source of state power is associated with British colonial rule and involved the imposition of a legal and bureaucratic system that enabled regulation and domination of 'Others' (Cohn, 1996).

Assistant professor Vinayak linked the dominance of positivist-quantitative methods to the Indian education system which favours 'anything that is number-based'. However, Amrit, a professor, noted that this tendency is not confined to India. The conflation of 'rigor' with 'statistical rigor' has recently been observed in the subfield of HRM (Harley, 2015) where it is associated with quantification and use of increasingly sophisticated statistical methods. This encourages training of researchers 'in methodological procedures, especially statistical techniques, so as to be able to carry out scientific work well’ (Hammersley, 2011, p.21). Adoption of positivist-quantitative methods is related to the superior status ascribed to numerical analysis which is seen as capable of delivering 'generalizability', even if this runs contrary to the researcher’s paradigmatic assumptions. 
Qualitative studies throw up questions, and generalisation is not an objective, but everyone wants... generalisation... We know that qualitative [research] is about diversity, it's not about generalisation. [The] mainstream would always like [it] to be homogenised. It is easy to deal with homogenised people. (Gyan, professor, emphasis added)

Dipanker, (professor), suggested quantification is driven by anxiety and a desire for legitimacy that cannot be satisfied using qualitative methods. Referring to the appeal of quantification and measurement, he comments that

especially in India, it is purely an overwhelming influence of the positivist paradigm... When I explain [interpretive research] to people... people immediately like it, but then... fall back into a, kind of, anxiety that, okay, will it be acceptable?

The popularity of quantitative methods is reinforced by a pragmatic belief that their use is less time-consuming and easier to publish, as a consequence of the prevalence of these methods in what are identified as the 'top' journals in the field. Lack of research training in qualitative methodologies was also identified by assistant professor Vinayak as contributing to a preference for quantitative methods.

I don't think there is a really good course on qualitative research, at least [at] the MBA level, anywhere in India. So that sort of creates a bias in the mind when we are... in the formative stage.

Associate professor Vinod suggested quantitative research was 'easier to manage', a view reinforced by Gyan, professor, who claimed it was more straightforward to get quantitative research published as there would be fewer 'questions' for the author 'to handle' during the 
review process. Dipanker estimated that ' $99 \%$ of $\mathrm{PhD}$ dissertations [in India are] limited to quantitative, statistically-based methods', with survey and experimental methods the most popular. The need to complete a PhD in a fixed time period and publish quickly from it was mentioned by several interviewees as discouraging qualitative, particularly ethnographic research, in addition to the widely acknowledged difficulty of writing up qualitative research within the length constraints of a standard journal article (see Easterby-Smith et al., 2008; Pratt, 2008). In this context, qualitative research is seen as an exploratory, inductive phase of the research process that assists quantitative researchers insofar as it contributes to the development of operationalizable constructs as a basis for hypothesis testing. This reinforces the primacy of positivist-quantitative methods and the genre of methodology-as-technique.

\section{Criteriology}

The third aspect of methodology-as-technique involves application of criteriological principles in the form of a 'permanent, stable criteria of rationality founded in the desire for objectivism' (Schwandt, 1996, p.58), manifest in application of concepts including validity, reliability and replicability. According to this logic, criteriology is the basis of research professionalism. While usually associated with quantitative study, case study research based on Yin (1984) and Eisenhardt (1989) is illustrative of the dominance of positivist criteriology in qualitative management research (Lee et al., 2007). This may be indicative of a 'positivist anxiety' (Prasad, 2005) which informs 'foundationalist' (Amis and Silk, 2008) or ‘neoempiricist’ (Johnson et al., 2006) management research. Criteriology encourages emulation of positivist-quantitative studies by researchers who work with qualitative data - for example by forming propositional statements similar to hypotheses or performing statistical inter-rater reliability checks in order to conform to an 'intellectual milieu dominated by positivism' (Cornelissen et al., 2012, p.199). Suresh (professor) explained: 
even when they [doctoral students] do qualitative work, they have a positivistic frame of mind, so while they're picking up soft data ... their mind is still positivistic... I think some of my students don't have the confidence.

Application of positivist criteriology is implied when terms like 'rigor', 'generalizability', 'validity' and 'robustness' were used by interviewees without explicit acknowledgment of the particularity of the epistemological and ontological assumptions that underpin them. Where a notion of rigor is aligned with positivism, its meaning is bound up with the pursuit of empirical generalizability and replicability. When invited to elaborate on what they meant by rigor and robustness, interviewees often struggled, falling back on proceduralism.

What I mean is... the well accepted practices that we are expected to undertake when we do research and publish in leading journals... the acceptable... ways of doing research, the robustness of it, the quality of it and so on and so forth... When I say robustness I mean... following proper procedure. (Ashok, UK-based associate professor)

Others responded by identifying where methodological rigor is found.

The leading American journals are very, very rigorous... methodological rigor is, of course, the necessity if you want to publish in American journals, whether it is quantitative or qualitative. (Dipanker, professor)

The association of rigor with North American, rather than European or Indian journals, reinforces a circular logic of quality whereby quantitative-positivist, rather than qualitativeinterpretive work is privileged (Grey, 2010). UK-based professor Manoj related rigor and 
robustness to research practices in the West explaining that he decided to leave India to do his $\mathrm{PhD}$ because studying in a 'reputed place' was necessary 'to do a really good piece of research' that is 'robust' and 'scientific'. Manoj further emphasised the importance of building such scientific research capability among Indian management researchers, expressing the view that much of their research is currently 'below average', and suggesting this was 'mainly related to training and... the [lesser] awareness which [Indian] scholars have' of global research practices, by which we understand him to mean the practices evident in articles appearing in 'top' journals. This statement promotes production of ostensibly universal knowledge about methodology as it is understood as something that can be transferred from the North American centre to peripheral locations.

The dominance of methodology-as-technique obliges researchers to emulate positivist criteria, or construct recognisable surrogates, whatever methodology is used. This 'positivistic frame of mind' (Suresh, professor) incentivises researchers to design and evaluate their own work according to what is taken to be a universal understanding of research quality, as indicated by use of the term 'sample' in qualitative research.

The challenge in qualitative research is that our sample is not good enough and we're not choosing the sample... Once you... select a good sample, if you can apply good qualitative research techniques, I think that is the best. (Paul, dean of faculty)

Conversely, there is little acknowledgement of a contingent criteriology (Johnson et al., 2006), including the relevance of specific criteria aligned with qualitative research such as ‘trustworthiness’ and ‘authenticity’ (Guba and Lincoln, 1994).

\section{Methodolatry}


The final element of the methodology-as-technique genre involves a pervasive preoccupation with methodological concerns over and above other considerations (Chamberlain, 2000). Described by Berger (2002) as ‘methodological fetishism’, this attitude to research privileges mastery of technique, often with the ambition of removing sources of bias. In so doing, the perfection of technique can become more important than the purpose the research claims to serve (see also Janesick, 1994). This type of goal displacement is by no means reserved for research undertaken at the periphery, as Anindita (professor) explained:

The method has taken over the question and the research process itself... the pressure to publish also has led to a certain gaming of the system and adding one little variable and studying it further... So these have become more like variable studies than real questions that one is curious about.

Methodolatry encourages a canonical approach where the primary concern is to identify 'good' methods and ensure novice researchers use them 'correctly'. This can apply to any method but it has become most deeply entrenched in the use of quantitative methods and statistical analysis. Methodolatry may also arise in qualitative research but is less common and less entrenched as many qualitative methodologies have multiple variations, making it more difficult to identify a clear canonical path (Chamberlain, 2000), although as noted earlier there are influential attempts to provide one (e.g. Yin, 1984). Where methodolatry prevails, it encourages the use of 'increasingly sophisticated methods to study increasingly trivial topics’ (Berger, 2002, p.28). Indeed, where researchers become dogmatically committed to a set of methodological procedures, these do 'not allow them to study anything else’ (Mills, 1959, p.72). As a consequence, concerns about method can become a 'sacred preoccupation’ (Schwandt, 1996) as researchers search out topics and identify research questions that are most readily amenable to the application of favoured methods. 
Methodolatry was implied by Souvik (associate professor), who spoke of how many researchers in India are 'fascinated' by the 'beauties' of quantitative methods. Similarly, assistant professor Vinayak stated that Indian researchers 'feel that the mastery is in the method'. Privileging methodological exactitude over all other considerations produces research that US-based professors Sameer and Haider characterise as 'derivative' and 'conformist'. The fetishism of technique is apparent in the words of assistant professor Dipesh, who presumes that qualitative research differs from qualitative research only in the distinctive techniques it deploys, and not in epistemological or ontological orientation.

Analysing the qualitative data, I think that's one of the most difficult parts, in the sense that I thought it was not included enough [in research training], this technique of analysing qualitative data... It is not that the qualitative research doesn't have defined techniques, but we are not exposed enough.

Methodolatry contributes towards the generation of safe, formulaic (Alvesson and Gabriel, 2013) or 'cookbook’ (Gioia et al., 2012) research where, for example, theory building readily assumes the form of complex diagrammatic models referred to as 'flow charting' (Chamberlain, 2000).

\section{The influence of rankings}

Moving beyond Hammersley's framework, it is important to note how international business school rankings play a significant role in framing judgements of research quality (Macdonald and Kam, 2007; Butler and Spoelstra, 2014) and evaluations of methodological rigor. Respondents spoke of the growing normative pressures on Indian management researchers to publish in 'top' journals, where the genre of methodology-as-technique is strongly 
represented and deeply entrenched. Prior to the use of such rankings, academic reputations of Indian management researchers were based on teaching and consultancy as well as research. However, the shift towards publishing in ‘top’ journals was driven by institutional pressures.

Every school... in India especially... wants to become something in the international [ranking and this] has research in certain kinds of journals as... the main thing in ranking. So ranking has become a big deal. (Anindita, professor)

The dominance of conceptions of rigor based on the genre of methodology-as-technique has implications for the type of knowledge that is deemed relevant (see Srinivas, 2008). Suresh noted how US-trained researchers in Indian management schools have long been 'telling us what research means and how to do it'. Increasingly, however, the nature of this prescriptive relationship has narrowed and intensified. Now, a $\mathrm{PhD}$ graduate seeking employment in a premier institution

should have at least a revise-and-resubmit ... should be on the path of publication in a top journal... and then they will start referring to people who are saying... 'what is the way to get into a top journal?' Then... you say... 'quantitative work is the one that will get you there faster ...[while] qualitative ... just takes more time, both in terms of doing it as well as in terms of publishing it’. (Suresh, professor)

Interviewees connected the comparative appeal of positivist-quantitative methodologies to the appointment of US faculty. As Srinivas (professor) pointed out, adopting methodologyas-technique is expedient in a job market where

there are a lot of US faculty who are moving to India... not coming as a...fresh $\mathrm{PhD}$... we have a few of them in [name of the institute] ... [who] have completed ten years or 12 years in academia... [they have] three publications in top journals... so that has actually made the 
market very difficult for people who are just graduating from the IIMs who may not have a top journal publication straight out.

UK-based associate professor Ashok commented: 'Americans look for hard numbers, positivist, deductive methods... they want figures, they want stats'. That the value of researchers is increasingly dependent on their journal publication record, irrespective of other contributions to scholarship, teaching and community (Murphy and Zhu, 2012), was emphasized by assistant professor, Shivam.

When I joined, in my appointment letter it was mentioned that I am supposed to publish two articles, and I was on probation for one year... [after one year] when my performance was appraised, my feedback from the classes was good and my admin was also good. I was able to meet those two criteria... but I [had] not fulfilled [the] condition given... in the appointment letter, so the [director] gave a comment that a conditional confirmation can be extended... We have certain targets wherein you are supposed to publish a minimum...on the ABDC classification... our director... emphasizes on the research part... in informal conversations also when we meet him...he promptly asks us what is our current research history... that pressure is there.

As noted by Dipanker (professor) the increased significance given to rankings is political as well as institutional.

In the last few years... the government of India has taken a position, [using] a particular journal ranking system... which is largely governed by American... dominated academia and... [this] has largely been supporting mainly positivist, quantitative research. 
Interviewees referred to the financial incentives being offered by IIMs to those who publish in 'top', 'A-class' or 'top tier' journals where the 'methodology-as-technique' genre has been naturalised.

\footnotetext{
We are constantly on scales of... 'how many tier one papers do you produce, etc.?' And when you look at those tier one papers, they're very positivist theory papers... That is putting... pressure not only on our doctoral students, but also on our junior faculty... There are a lot of us who are in the system, we just were coerced into doing more positivistic work... (Suresh, professor)
}

It is important to recognize that the irony of these pressures, in terms of narrowing research issues and topics as well as devaluing of other methodologies, is not lost on researchers like Dipanker.

Most of the Indian journals are not on those lists and if we become dependent only on mostly American journals, not even European, then we are actually putting another constraint [on]to more contextual... research, and that is also restricting choice of methods (emphasis added).

Such observations are not unique to the Indian context but they help to account for why a particular genre of research has become dominant and almost exclusive.

\section{Denaturalising methodology-as-technique}

To conform to the requirements of methodology-as-technique, Indian management researchers are encouraged to overlook local realities in favour of demonstrating rigor in the narrowly defined sense expected by international journals. Assistant professor Ravish 
described how institutional pressures had discouraged him from taking the 'risk' associated with qualitative doctoral study.

[Someone will] propose to us: 'why not do one positivist study? ...do one survey... using their own methods, using their own variables, and put it in their own journals. And then see... what happens?' So we have been waylaid... we have been seduced, we have been coerced... into that kind of... contradictory... work as well.

Such views indicate both pressure to comply with the methodology-as-technique genre and hostility towards it. Associate professor Kaveri spoke of the need to resist the 'hegemony of certain [positivist and evidence based] methodologies' even if this was difficult. In seeking to explain the dominance of positivist methods, Dipanker (professor) suggested a broader connection with a central ideology of capitalism.

\footnotetext{
Management, academia, is... affected by... capitalist... economic ideology, and I think there is... a kind of resonance... between positivism and capitalism... Both are authoritarian, hegemonic, and so I think the management, academicians, managers, industrialists, they want objective knowledge... which is... validated... and validated mostly means in... quantitative terms.
}

Other respondents, including Anindita (professor), were cynical about the mystique of positivist-quantitative methods, suggesting that the growing sophistication of statistical techniques as having created a situation where 'if the reviewer can't understand it, all the better... and it seems like I've done a lot of work'. She was also critical of the effects of methodology-as-technique on the accessibility and relevance of research to non-specialist audiences. 
To me, a lot of the quantitative research today is... unreadable. It has become an exercise in fragmenting and using more and more sophisticated statistics, the whole argument is lost in the whole process.

This view was echoed by assistant professor Prashant, who expressed a concern about what is not researched.

I think a greater commitment to what is happening... around us in terms of the inequalities and injustices... is important. That is not being done. The effort is not being made... [Instead] one variable is being added... [to a theoretical framework that already exists], meaning the [generalisability] is...increased to some extent... Within the Indian social context... that kind of research is meaningless, perhaps even criminal.

Such observations suggest the experiences of Indian management researchers may provide a basis for critique and resistance by deconstructing the 'reality' of methodology-as-technique and the 'truthfulness' of the knowledge it produces. In the process, its un-naturalness and perverse consequences are disclosed. For those who encounter the genre of methodology-astechnique on the periphery, where its logic is less certain and its enactment less well established, what is presented as normal or authoritative may can be seen as alien or strange. This enables the 'mask of science' (Fournier and Grey, 2000, p.18) on which the genre of methodology-as-technique relies, to be detected and removed, opening up possibilities for greater reflexivity. In turn, such scepticism and resistance forms the basis for considering alternative methods and practices for generating social scientific knowledge.

\section{Discussion: Reconfiguring management research on a global scale}


Current institutional conditions have fostered the global dominance of, and engendered normative compliance to, the genre of methodology-as-technique, as exemplified by the experiences of Indian management researchers. Central to this is the use of international business school journal rankings that position as elite US journals where this genre has become established as 'normal science'. Alternative methodological genres are correspondingly constructed as less rigorous and more marginal. By paying attention to the voices of Indian management researchers, we have explored the ways in which precision, reliability and efficiency based on methodical, prudent and disciplined behaviour are, paradoxically, likely to restrict the reach and limit the relevance of management research and reduce the ability of management researchers to address society's grand challenges and ‘wicked problems’ (Brewer, 2013).

As our analysis further demonstrates, this can result in what Van Maanen (1995, p.139) describes as 'technocratic unimaginativeness' where researchers render 'organization theory safe for science'. When research methods are treated as 'neutral or technical solutions to data gathering problems' (Jack and Westwood, 2006, p.482), and rigor is defined in terms of rigid application of rules, this encourages displacement from goals onto means (Merton, 1957) and can have perverse, unintended consequences (Lawson, 2015). Through 'unchallenged insistence upon punctilious adherence to formalized procedures’ (Merton, 1957, p.199), reliance on the methodology-as-technique genre promotes research that is 'fastidious in...design and analytical sophistication’ (Anderson et al., 1991, p.395). By narrowing the focus on ever-greater refinement, methodology-as-technique discourages reflection on what is being done and why and obscures the ethical-political nature of the management research process and outcomes derived from it (Bell and Willmott, 2014). This trained incapacity to see methods as contingent upon context and relative to a set of purposes also has 
consequences for research relationships and the ability to conduct research of reciprocal value to participants and wider publics, rather than just for other researchers (Bell and Bryman, 2007).

Some suggest it is possible to address inequalities associated with the globalization of social science research by developing more context-specific (Tsui, 2007), contextualized (Nkomo, 2015) or 'glocalistic' methodologies (Gobo, 2011), where research methods developed in the Western core are adapted to take account of local cultural characteristics. However, these proposals downplay geopolitical power imbalances in the production of knowledge, including those that pertain to methodological practice and definitions of research rigor. We suggest the globalization of management research in the Indian context currently manifests a form of ‘neo-colonial globality’ (Muppidi, 2004) structured around domesticating difference and marginalizing voices from peripheral locations. Neo-colonial globality exemplifies a philosophy in which the 'world-as-a-whole' is named as the object of knowledge production and encompasses the global South in a way that enables modernist scientific methodologies to be played out on a larger geographical stage (Connell, 2007). This helps to explain why, although the contribution of management researchers from peripheral locations is increasing (Saunders et al., 2011), there is little evidence of the emergence of 'glocal' methodologies.

By pitching local against global, and focusing on context-specific study irrespective of the approach to knowledge creation that informs it, global management research fails to engage with the critique of Western science as the dominant ideology of the postcolonialist state (Connell, 2007) and an ideology driven by a desire to 'understand' the 'Other' (Prasad, 2003) as the basis of control through a particular conception of Enlightenment. The promotion of an 'international' or universalist approach to social science in India arises from the presumed 
superiority of research practices developed in the global North. Yet as Singh (1973, p.14) argues, this claimed superiority is based not on 'conceptual creativity' but rather the ‘technical virtuosity’ of methodologies and methods, particularly those associated with positivistic research. As he further suggests, such claims to superiority fail to acknowledge historical and cultural context, including the influence of Western value-judgements on theoretical abstractions like the meta-concepts of 'individual' and 'organization', which are exported and presented as universally agreed upon (see also Bell and Kothiyal, forthcoming). Scholars like Connell (2007) argue that social science research must not merely adjust existing theories, concepts and methodologies to take account of Indian experiences, in a kind of 'academic tourism' that treats peripheral contexts primarily as a context for collection of data. Instead researchers need to draw on philosophical, literary, artistic and religious traditions of knowledge that are indigenous to these contexts in order to develop a social science that problematizes pre-given social entities and reinvents them from a distinctly Indian perspective. This relies on challenging the embodied power relations that characterise management research as a global, commercial enterprise which leads to the creation of knowledge primarily via North American and European journals published in English.

Yet methodologies are 'living traditions not abstract recipes’ (Abbott, 2004, p.26), produced by communities of researchers through their practice, teaching and development (Connell 2007; Bell and Clarke, 2014). For those who experience the genre of methodology-astechnique on the periphery where its enactment is less well established, this presents an opportunity for denaturalization - whereby what is presented as normal comes to appear as alien or strange. Peripheral practices of denaturalization rely on problematizing the genre by showing that methodology is 'embedded in ontological and epistemological orientations and preferences, as well as the interests, motivations and values of the researcher [that are] 
themselves situated in a historically, institutionally, culturally, and ideologically informed context' (Jack and Westwood, 2006, p.482).

Denaturalization could enable management knowledge on a global scale to be reconfigured to take full and critical account of the role of Western neo-imperialism and colonialism (Denzin and Lincoln, 2005) in the historical formation of social scientific research (Smith, 1999). This would involve acknowledging philosophical traditions and belief systems that provide a counterweight to foundationalist Enlightenment narratives within which dominant understandings of management research are currently framed (Amis and Silk, 2008). It would also entail questioning taken-for-granted ways of organizing, conducting and disseminating knowledge in which there is a reliance upon empirical colonialism or 'studying down' (Harding, 1998). This would involve translating the experience of participants on the periphery into a discursive form which does not objectify them and reinscribe them as 'Other' (Smith, 1995), or reduce and mould them to 'the same'. Demonstrating the limits of the genre of methodology-as-technique, and its restrictiveness with regard to those who are 'Othered', could thereby open up spaces for indigenous research methodologies (Smith, 1999) that draw on local traditions of knowledge (Jackson, 2014).

The reconfiguration of management research on a global scale requires development and application of diverse methods, such as those based on narrative knowledge and storytelling (Kaomea, 2016), rather than continuing reliance on variants of the genre of methodogy-astechnique that assume and reinforce existing ways of knowing. In taking up this challenge, management researchers on the periphery would be framed as bricoleurs (Denzin and Lincoln, 2005), rather than technicians, piecing together research methods creatively so as 'to make previously repressed features of the social world visible and seek to challenge the 
hegemonic status quo’ (Kaomea, 2016, p.100). Such analyses pay attention to, and are respectful of, local actors’ definition(s) of the situation, as a dynamic meaning-making process and a negotiated outcome of relations of power. This approach presents a challenge inter alia to liberal Enlightenment conceptions of the autonomous self by taking seriously traditions of knowledge in which identities are considered to be relational and intersubjective (Stevenson, 2016) $)^{\text {vii }}$.

The reconfiguration of global management research relies on fostering awareness that language is not a neutral resource. The use of English as the dominant mode of representation in international publishing operates to reinscribe power relations associated with colonial oppression (Meriläinen et al., 2008; Murphy and Zhu, 2012; Li and Parker, 2013). Western theoretical traditions rely on mastery of a language of abstraction and the methods of science that are used to enhance the authority of the speaker through conceptual detachment (Shope, 2006). An alternative globality could incorporate orality (Willox et al, 2012) and visuality (Bell and Davison, 2013) as distinctive modes of knowing and representing management knowledge. This reconfiguration could expand the use of innovative methods of analysis and dissemination, such as participatory organizational research (Burns et al, 2014), or digital storytelling (Willox et al, 2012) to illuminate and critically affirm the value of indigenous understandings. Reconfigured globality may also involve going beyond human-centric approaches to knowledge to explore diverse forms of knowing, including those that draw on spirituality and/or that are linked to ecological belief systems (Willmott, 2014).

There are implications for research ethics arising from this proposed reconfiguration. Alternative globality entails questioning governance practices that place indigenous peoples in a subaltern position of dependence where they are considered to need outsider assistance 
(Stevenson, 2016). This favours an ethics based on reciprocity (Bell and Bryman, 2007) and respectful collaboration fused with the nurturing of critical reflection. It requires the cultivation of researcher reflexivity as a basis for understanding how, in the use of social scientific methods, management researchers actively participate in and enact social realities and engage in a relational co-production of knowledge (Cunliffe, 2011). Such awareness involves moving away from a tradition that represents the indigenous Other as an object of study, based on Western methodological traditions that privilege the genre of methodologyas-technique.

\section{Conclusion}

Patterns of knowledge production in management research, and the methodological practices and notions of rigor on which they rely, risk becoming increasingly narrow and isomorphic (Alvesson and Gabriel, 2013). This article has highlighted the processes and practices through which understandings of methodological rigor are constructed in management research in ways that fetishize technique. We readily acknowledge that the conditions described by Indian management researchers are also encountered by Western researchers, regardless of whether their work conforms to the genre of methodology-as-technique. But we have also suggested that there are important differences arising from the latter's neo-colonial position. Scholars in peripheral locations not only observe and perpetuate these global conditions but, by virtue of their marginality, are comparatively well placed to question and denaturalize their norms. Indigenous scholars may then come to play an increasingly important role in countering the homogenizing and perverse effects associated with scholarship dominated by the methodology-as-technique genre, particularly if, as Connell (2007) suggests, management researchers located in South Africa, Brazil and India organize 
laterally with scholars in other peripheral locations to identify common interests and overlapping problem areas and form networks of cooperation and knowledge sharing that challenge intellectual dependency on the West. By questioning and challenging the practices and institutions that foster this genre, scholars in peripheral regions may open up methodological spaces for more diverse post-Enlightenment narratives.

As we have argued, methodologies do not simply describe or capture realities, they also constitute them (Law, 2004). Rather than being vested in a single set of criteria, judgements of rigor are integral to the purpose and ethical positioning of management researchers. Because judgements of research quality are indistinguishable from morality and axiology, the production of knowledge involves taking 'a stand on what it is right to do and good to be as social inquirers’ (Schwandt, 1996, p.59; see also Ezzamel and Willmott, 2014). This orientation is consistent with the proposed reframing of globalized research as a condition of possibility for the pluralisation and re-enchantment of management research practice and depends upon the release of management research from the confines of a narrow and deeply entrenched conception of rigor. 


\section{References}

Abbott, A. (2004). Methods of Discovery: Heuristics for the Social Sciences. New York: Norton.

Alcadipani, R. and Caldas, M.P. (2012). ‘Americanizing Brazilian management’, Critical Perspectives on International Business, 8, pp. 37-55.

Alvesson, M. and Deetz, S. (2000). Doing Critical Management Research. Thousand Oaks: Sage.

Alatas, S. F. (2003). 'Academic dependency and the global division of labour in the social sciences’, Current Sociology, 51, pp. 599-633.

Alvesson, M. and Gabriel, Y. (2013). ‘Beyond formulaic research: In praise of greater diversity in organizational research and publications’, Academy of Management Learning \& Education, 12, pp. 245-263.

Alvesson, M., and Sandberg, J. (2011). ‘Generating research questions through problematization', Academy of Management Review, 36, pp. 247-71.

Amis, J. and Silk, M. (2008). 'The philosophy and politics of quality in qualitative organizational research’, Organizational Research Methods, 11, pp. 456-480.

Anderson, N., Heriot, G.P. and Hodgkinson, G. (2001). 'The practitioner researcher divide in industrial work and organizational psychology: Where are we now and where do we go from here?’ Journal of Occupational and Organizational Psychology, 74, pp. 391-411.

Aram, J.D. and Salipante, P.F. (2003). ‘Bridging scholarship in management: Epistemological reflections’, British Journal of Management, 14, pp. 189-205.

Atkinson, P., Coffey, A. and Delamont, S. (2003). Key Themes in Qualitative Research: Continuities and Changes. Oxford: AltaMira Press 
Baum, J. A. C. (2007). 'Cultural group selection in organization studies’. Organization Studies, 28, 37-47.

Banerjee, A. (2013). ‘Academic research productivity: What may be "reining” in the Indian B-School?’ IIM Working Paper Series No. 2013-06-06.

Becher, T. (1989). Academic Tribes and Territories: Intellectual Enquiry and the Cultures of Disciplines. Buckingham: SRHE and Open University.

Bell E. and Bryman A. (2007). 'The ethics of management research: An exploratory content analysis’, British Journal of Management, 18, pp. 63-77.

Bell, E. and Clarke, D. (2014). 'Beasts, burrowers and birds: The enactment of researcher identities in UK Business Schools’, Management Learning, 45, pp. 249-266.

Bell, E. and Davison, J. (2013). 'Visual management studies: Empirical and theoretical approaches’, International Journal of Management Reviews, 15, pp. 167-184.

Bell, E. and Kothiyal, N. (forthcoming). 'Ethics creep from the core to the periphery'. In C. Cassell, A. Cunliffe and G. Grandy (eds) SAGE Handbook of Qualitative Business and Management Research Methods.

Bell, E. and Willmott, H. (2014). ‘Editor's introduction: qualitative research - Themes and prospects’. In Bell, E. and Willmott, H. (eds), Major Works in Qualitative Research in Business and Management, pp. xxi-liv, London: Sage.

Berger, P. (2002). ‘Whatever happened to sociology?’ First Things, 126: pp. 27-9.

Bluhm, D.J., Harman, W., Lee, T.W. and Mitchell, T.R. (2011). 'Qualitative research in management: A decade of progress', Journal of Management Studies, 48, pp. 1866-1891. Brewer, J. (2013). The Public Value of the Social Sciences. London: Bloomsbury. Bryman, A. (1998). 'Quantitative and qualitative research strategies in knowing the social world’. In May, T. and Williams, M. (eds), Knowing the Social World, pp. 138-156, Milton Keynes: Open University Press. 
Burns, D., Hyde, P., Killet, A., Poland, F. and Grey, R. (2014). 'Participatory organizational research: Examining voice in the co-production of knowledge', British Journal of Management, 25, pp. 133-144.

Butler, N. and Spoelstra, S. (2014). 'The regime of excellence and the erosion of ethos in Critical Management Studies’, British Journal of Management, 25, pp. 538-550.

Chamberlain, K. (2000). 'Methodolatry and qualitative health research', Journal of Health Psychology, 5, pp. 285-296.

Chawla, D. and Sondhi, N. (2011). Research Methodology. (1 $1^{\text {st }}$ edition). Delhi: Vikas Publishing.

Cohn, B.S. (1996). Colonialism and its Forms of Knowledge: The British in India. Princeton, NJ: Princeton University Press.

Connell, R., 2007. Southern Theory: Social Science and the Global Dynamics of Knowledge. Oxford: Polity Press.

Cooke, B. and Alcadipani, R. (2015). 'Towards a global history of management education: The case of the Ford Foundation and the São Paolo School of Business Administration, Brazil’, Academy of Management Learning \& Education, 14, pp. 482-499.

Cooper, D. and Schindler, P. (2011). Business Research Methods. (11 ${ }^{\text {th }}$ international edition). New York: McGraw Hill.

Cornelissen, J., Gajewska-De Mattos, H., Piekkari, R. and Welch, C. (2012). 'Writing up as a legitimacy seeking process: Alternative Publishing Recipes for Qualitative Research’. In Symons, G. and Cassell, C. (eds), Qualitative Organizational Research, pp. 184-203. London: Sage.

Cunliffe, A. (2011). 'Crafting qualitative research: Morgan and Smircich 30 years on’, Organizational Research Methods, 14, pp. 647-673 
Daft, R.L. (1980). 'The evolution of organisational analysis in ASQ 1959-1979’,

Administrative Science Quarterly, 26, pp. 207-24.

Denzin, N. and Lincoln, Y. (2005). ‘The discipline and practice of qualitative research’. In

Denzin, N. and Lincoln, Y. (eds), Handbook of Qualitative Research, pp. 1-32. Thousand Oaks CA: Sage.

Easterby-Smith, M., Golden-Biddle, K. and Locke, K. (2008). 'Working with pluralism: Determining quality in qualitative research’, Organizational Research Methods, 11, pp. 419429.

Eisenhardt, K. M. (1989). 'Building theories from case study research', Academy of Management Review, 14, pp. 532-50.

Ezzamel, M. and Willmott, H.C. (2014). 'Registering "the ethical” in organization theory formation: Towards the disclosure of an "invisible force”, Organization Studies 35, pp. 1013-1039.

FICCI, (2011). Private Sector Participation in Indian Higher Education. FICCI Higher Education Summit. Kolkata: Ernst \& Young.

Fournier, V. and Grey, C. (2000). 'At the critical moment: Conditions and prospects for Critical Management Studies’, Human Relations, 53, pp. 7-32.

Geertz, C. (1974). ““From the native’s point of view”: On the nature of anthropological understanding', Bulletin of the American Academy of Arts and Sciences, 28, pp. 26-45. Ghoshal, S. (2005). Bad management theories are destroying good management practices’, Academy of Management Learning \& Education, 2005, 4, 1, pp. 75-91

Gilles, V., and Aldred, P. (2012). 'The ethics of intention: Research as a political tool'. In T. Miller, M. Birch, M. Mauthner and J. Jessop (eds), Ethics in Qualitative Research, pp. 43-60. London: Sage.

Gioia, D.A., Corley, K.G., and Hamilton, A.L. (2012). 'Seeking qualitative rigor in inductive research: Notes on the Gioia Methodology’, Organizational Research Methods, 16, pp. 15-31. 
Gobo, G. (2011). 'Glocalizing methodology? The encounter between local methodologies', International Journal of Social Research Methodologies, 14, pp. 417-437.

Grey, C. (2010). 'Organizing studies: Publications, politics and polemic’, Organization Studies, 31, pp. 677-694.

Guba, E. G., and Lincoln, Y. S. (1994). ‘Competing paradigms in qualitative research’. In N. K. Denzin and Y. S. Lincoln (eds), Handbook of Qualitative Research, pp. 105-117. Thousand Oaks, CA: Sage.

Harding, S. (1998). Is Science Multicultural? Postcolonialism, Feminism and Epistemologies. Bloomington: Indiana University Press.

Harley, B. (2015). 'The one best way? Scientific research in HRM and the threat to critical scholarship’, International Human Resource Journal, 25, pp. 399-407. Hanna, P (2012). ‘Using Internet technologies (such as Skype) as a research medium: A research note’, Qualitative Research, 12, pp. 239-242.

Hammersley, M. (2011). Methodology: Who Needs It? London: Sage.

Ibbaro-Colado, E. (2006). 'Organization studies and epistemic coloniality in Latin America: Thinking otherness from the margins', Organization, 13, pp. 463-488.

Jackson, T. (2014). ‘How can we encourage indigenous research?', International Journal of Cross Cultural Management, 14, pp. 135-137.

Janesick, V.J. (1994). The dance of qualitative research: Metaphor, methodolatry, and meaning'. In N.K. Denzin and Y.S. Lincoln (eds), Handbook of Qualitative Research, pp. 209-219. Thousand Oaks: Sage.

Johnson, P., Buehring, A., Cassell, C.M. and Symon, G. (2006). 'Evaluating Qualitative Management Research: Towards a Contingent Criteriology’, International Journal of Management Reviews, 8, pp. 131-156. 
Kaomea, J. (2016). ‘Qualitative analysis as Ho‘oku'iku'i or bricolage: Teaching emancipatory indigenous research in postcolonial Hawai ‘i’, Qualitative Inquiry, 22, pp. 99106.

Khatri, N., Ojha, A.K., Budhwar, P., Srinivasan, V. and Varma, A. (2012). 'Management Research in India: Current State and Future Directions’, IIMB Management Review, 24: pp. 104-115.

Knorr Cetina, K. (1999). Epistemic Cultures: How the Sciences Make Knowledge. Harvard: Harvard University Press.

Law, J. (2004). After Method: Mess in Social Science Research. London: Routledge. Lawson, T. (2015). 'Mathematical modelling and ideology in the economics academy: Competing explanations of the failings of the modern discipline?' In Lawson, T. (ed), The Nature and State of Modern Economics, pp. 142-168. London: Routledge. Lee, B., Collier, P. M., and Cullen, J. (2007). 'Reflections on the use of case studies in the accounting, management and organizational disciplines’, Qualitative Research in Organizations and Management: An International Journal, 2, pp. 169-78.

Li, E. Y. and Parker, M. (2013). 'Citation patterns in organization and management journals: Margins and centres’, Organization, 20, pp. 299-322.

Macdonald, S. and Kam, J. (2007). ‘Ring a ring o’ roses: Quality journals and gamesmanship in management studies’, Journal of Management Studies, 44, pp. 640-655.

Meriläinen, S., Tienari, J., Thomas, R. and Davies, A. (2008). 'Hegemonic academic practices: Experiences of publishing from the periphery’, Organization, 15, pp. 584-596. Merton, R.K. (1957). Social Theory and Social Structure. New York: Free Press. Mills, C.W. (1959). The Sociological Imagination. Oxford: Oxford University Press. Mingers, J. and Willmott, H. (2013). 'Taylorizing business school research: On the 'one best way’ performative effects of journal ranking lists’, Human Relations, 66, pp. 1051-1073. 
Mir R., Mir A. and Srinivas N. (2004). 'Managerial knowledge as property: the role of universities’, Organization Management Journal, 1, pp. 126-137.

Mohan, T.T.R. (2011) Brick by Red Brick. New Delhi: Rupa Publications.

Murphy, J. and Zhu, J. (2012). 'Neo-colonialism in the academy? Anglo-American domination in management journals’, Organization, 19, pp. 915-927.

Muppidi, H. (2004). The Politics of the Global. Minneapolis: University of Minnesota Press. Newell, R.W. (1986). Objectivity, Empiricism and Truth. London: Routledge and Kegan Paul.

Nigam, A. and Trujillo, D. (2016). 'Quantification as a philosophical act'. In R. Mir, H. Willmott and M. Greenwood (eds), The Routledge Companion to Philosophy in Organization Studies, pp. 525-531.

Nkomo, S.M. (2015). 'Challenges for management and business education in a “developmental state”: The case of South Africa’. Academy of Management Learning \& Education, 14, pp. 242-258.

Panda, A. and Gupta, R. K. (2014). 'Making academic research more relevant: A few suggestions’, IIMB Management Review, 26, pp. 156-169.

Paulus, T.M., Lester, J.N. and Britt, V.G. (2013). 'Constructing hopes and fears around technology: A discourse analysis of introductory qualitative research texts', Qualitative Inquiry, 19, pp. 639-651.

Prasad, P. (2003). 'The return of the native: Organizational discourses and the legacy of the ethnographic imagination’. In A. Prasad (ed), Postcolonial Theory and Organizational Analysis: A Critical Engagement, pp. 149-170. Basingstoke: Prentice Hall. Prasad, A. (2005). Crafting Qualitative Research: Working in the Postpositivist Traditions. Armonk, New York: M.E. Sharpe. 
Pratt, M.G. (2008). 'Fitting oval pegs into round holes: Tensions in evaluating and publishing qualitative research in top-tier North American journals', Organizational Research Methods, 11, pp. 481-509.

Ryen, A., and Gobo, G. (2011). 'Managing the decline of globalized methodology’. International Journal of Social Research Methodology, 14, pp. 411-415.

Saunders, J., Wong, V. and Saunders, C. (2011). 'The Research Evaluation and Globalization of Management Research’, British Journal of Management, 22, pp. 401-419.

Schwandt, T.A. (1996). 'Farewell to criteriology’, Qualitative Inquiry, 2, pp. 58-76.

Schwartz-Shea, P. (2014). 'Judging quality: Evaluative criteria and epistemic communities'. In Yanow, D. and Schwartz-Shea. P. (eds), Interpretation and Method: Empirical Research Methods and the Interpretive Turn, pp. 120-146. New York: M.E. Sharpe. Schwartz-Shea, P. and Yanow, D. (2002). “”Reading” "methods” “texts”: How research methods construct political science’, Political Research Quarterly, 55, pp. 457-486. Scott, J.C. (1998). Seeing like a State: How Certain Schemes to Improve the Human Condition Have Failed. New Haven, CT: Yale University Press.

Sheel, R. and Vohra, N. (2014). 'Fostering academic research among management scholars in India: An introduction to the special issue'. VIKALPA, 39, pp. v-xi.

Sheth, N. R. (1991). 'What is wrong with management education', Economic and Political Weekly, pp. M123-M128.

Shope, J.H. (2006). “"You can't cross a river without getting wet”: A feminist standpoint on the dilemmas of cross-cultural research'. Qualitative Inquiry, 12, pp. 163-184.

Shrivastava, P. (1987). 'Rigor and practical usefulness of research in strategic management', Strategic Management Journal, 8, pp. 77-92.

Silverman, D. (1970). The Theory of Organizations. London: Heinemann. 
Singh, Y. (1973). 'The role of social sciences in India: A sociology of knowledge', Sociological Bulletin, 22, pp. 14-28.

Smith, L.T. (1999). Decolonizing Methodologies: Research and Indigenous Peoples. London: Zed Books.

Smith, L.T. (2005). 'On tricky ground: Researching the native in the age of uncertainty'. In N. Denzin and Y. Lincoln (eds), Handbook of Qualitative Research, pp. 85-107. London: Sage.

Srinivas, N. (2008). 'Mimicry and revival: The transfer and transformation of management knowledge to India, 1959-1990’, International Studies of Management and Organization, 38(4): 38-57.

Stevenson, S.A. (2016). 'Toward a narrative ethics: Indigenous community-based Research, the Ethics of Narrative, and the Limits of Conventional Bioethics’, Qualitative Inquiry, 22, pp. 365-376.

Swadener, B.B. and Mutua, K. (2008). 'Decolonizing performances: Deconstructing the global postcolonial’. In N. Denzin, Y. Lincoln \& L.T. Smith (eds), Handbook of Critical and Indigenous Methodologies, pp. 31-43. Thousand Oaks CA: Sage.

Tsui, A. S. (2007). ‘From homogenization to pluralism: international management research in the Academy and beyond'. Academy of Management Journal, 50, pp. 1353-64.

Üsdiken, B. (2014). 'Centres and peripheries: Research styles and publication patterns in ‘top’ US journals and their European alternatives, 1960-2010’, Journal of Management Studies, 51, pp. 764-789.

Van Maanen, J. (1995). ‘Style as theory’, Organization Science, 6, pp. 133-143.

Willmott, H.C. (2014). 'Science, governance and self-understanding: From anthropocentrism to ecocentrism’. Critical Policy Studies, 8, pp. 22-40.

Yin, R. K. (1984). Case Study Research: Design and Methods. Beverly Hills, CA: Sage. 
Willox, A.C., Harper, S.L., Edge, V.L., 'My Word': Storytelling and Digital Media Lab and

Rigolet Inuit Community Government (2012). ‘Storytelling in a digital age: Digital

storytelling as an emerging narrative method for preserving and promoting indigenous oral

wisdom’, Qualitative Research, 13, pp. 127-147.

Zikmund, W.G., Babin, B.J., Carr, J.C. and Griffin, M. (2010). Business Research Methods,

( $8^{\text {th }}$ international edition). Connecticut: South Western-Cengage Learning.

\footnotetext{
'The use of the word 'international' in this context takes no account of neo-colonial power relations since it equates to the adoption of 'national' - primarily US - research practices worldwide.

ii Hammersley's (2011) other two genres are 'methodology-as-philosophy', which incorporates the ontological and epistemological assumptions used to justify different approaches to research. The third genre, 'methodology-as-autobiography', conceives of research as a messy, creative and unfolding process learnt through first-hand experience. Within this genre, attention is directed to the dynamic character of research and consideration is given to the interdependent relationship between the researcher and the production of knowledge.

iii These two IIMs, particularly Ahmedabad, played a pivotal role in shaping management education in India through academic and executive training. They regularly organized faculty development programmes for management faculty in other Indian universities (Mohan 2011, p.117).

${ }^{\text {iv }}$ Identified using Bookscan figures which indicate the number of copies sold through retailers. While this does not give a completely reliable number in terms of number of copies sold, it enables identification of relative market share. Cooper and Schindler (eleventh edition, 2011) as well as Zikmund et al. (eighth edition, 2010) are North American-based authors. The texts are equally placed for readership and sales. Chawla and Sondhi (first edition, 2011) are Indian-based co-authors.

${ }^{v}$ In this respect, we acknowledge that our own approach, is partially compliant with the genre of methodologyas-technique through adopting purposive sampling, for example, and undertaking analysis using NVivo.

${ }^{\mathrm{vi}}$ Coverage of qualitative research methods in Zikmund et al. (2010) is mainly in two chapters (7 \& 11), but a positivist tone is maintained, e.g. section on 'Errors associated with direct observation' (243-4), and 'Content Analysis’ (quantitative rather than qualitative). In Cooper and Schindler (2011), one chapter out of 21 focuses on qualitative research; and Chawla and Sondhi (2011) devote one chapter out of 20 to qualitative research.

vii The creative use of focus groups as a way of facilitating plurality of voices, rather than individual monologue or dialogue with a researcher, provides just one example of a method through which greater relational understandings might be achieved (Shope, 2006).
} 